\title{
Krótka historia samochodu w Polsce i zastosowanie spawania w naprawach części samochodowych
}

\author{
A brief history of the automobile in Poland \\ and application of welding in the repair of automotive parts
}

\section{Streszczenie}

W Polsce przedsiębiorstwa zajmujące się produkcją samochodów powstały dopiero w latach dwudziestych $\mathrm{XX}$ wieku. Istniały natomiast liczne warsztaty, zajmujące się naprawą zużytych elementów. W artykule przedstawiono historię rozwoju motoryzacji, a także możliwości regeneracji części samochodowych metodami spawalniczymi.

Słowa kluczowe: motoryzacja, części samochodowe, regeneracja

\section{Abstract}

In Poland, the company engaged in the production of cars arose only in the twenties of the twentieth century. There were however a number of workshops dealing with the repair of worn parts. The article presents the history of the development of the automotive industry, as well as the possibility of recovery of auto parts welding methods.

Keywords: automotive, auto parts, regeneration

\section{Wstęp}

Zagadnienie możliwości przemieszczania się człowieka były zawsze przedmiotem zainteresowania nauki i techniki. Każdy wynalazek starano się, w ten czy inny sposób, zastosować do budowy środków transportu. Już w pierwszej połowie XIX wieku zostały podjęte próby budowy samojazdów (samochodów) parowych i elektrycznych.

Za datę wynalezienia silnika spalinowego uważa się rok 1860, w którym E. Levar zbudował pierwszy silnik spalinowy, wykorzystujący mieszankę gazu ziemnego i powietrza W 1876 r. Otto i Langen zbudowali silnik gazowy czterosuwowy, na podstawie którego G. Daimler w 1883 r. zbudował pierwszy silnik benzynowy. Silnik ten został od razu zastosowany przez Daimlera w zbudowanym przez niego w 1885 r. pierwszym samochodzie benzynowym [1].

\section{Motoryzacja w Polsce}

Pierwszy samochód pojawił się w Warszawie w $1896 \mathrm{r}$. [2]. Był to pojazd akumulatorowy, o mocy $3 \mathrm{kM}$, służący do przewozu 4 osób. Zainteresowanie nowym środkiem lokomocji było znaczne, dlatego już w 1897 r. na łamach Przeglądu Technicznego ukazał się artykuł F. Wojciechowskiego, opisujący rozwój konstrukcji samochodów [1].

Do 1918 r. na obszarze Rzeczypospolitej nie było ani jednego przedsiębiorstwa zajmującego się produkcją samochodów $[3,4]$. Istniały jedynie warsztaty naprawcze, z których największymi były Centralne Warsztaty Samochodowe w Warszawie [3] W warsztatach tych, zatrudniających 120 robotników, naprawiano 5-12 samochodów miesięcznie. Były to głównie samochody wojskowe, odebrane okupantom, gdyż nieliczne przed wojną samochody osobowe zostały zarekwirowane dla potrzeb wojska. Z czasem znacznie wzrosło zatrudnienie i możliwości produkcyjne C.W.S.; w 1920 r. remontowano już 100 wozów miesięcznie, zatrudnienie wzrosło do 450 osób, a w 1927 r. do 1075 osób [4]. Od 1923 r. w Warsztatach rozpoczęto montaż samochodów z własnych części, a dwa lata później powstał pierwszy samochód polskiej konstrukcji [2]. Był to model CTS T-1 (rys. 1), po raz pierwszy zaprezentowany na targach we Lwowie w 1925 r. Samochód ten produkowano w krótkich seriach od 1927 r. i przez 4 lata wyprodukowano ponad 800 pojazdów. Wysoka cena spowodowała, że zaniechano produkcji tego samochodu, zastępując go licencyjnym Fiatem 508 [5].

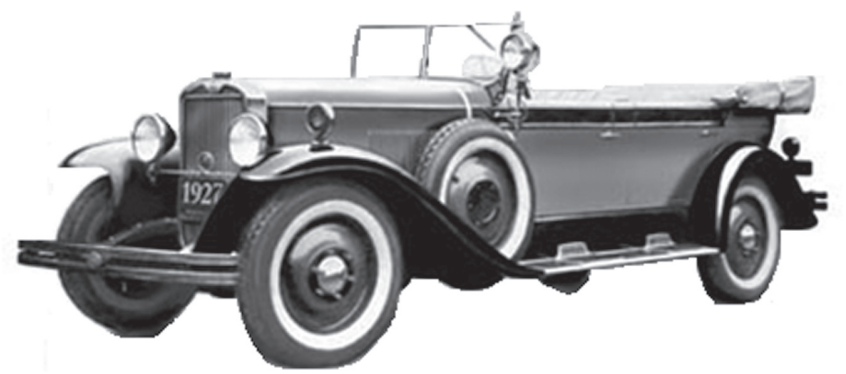

Rys. 1. Pierwszy samochód polskiej konstrukcji CTS T-1 [5]

Fig. 1. The first Polish car CTS T-1 [5]

Dr inż. Anna Pocica - Politechnika Opolska.

Autor korespondencyjny/Corresponding author. a.pocica@po.opole.pl 
Kolejne - Zakłady Mechaniczne Ursus Sp. Akc. powstały w 1924r. w Czechowicach koło Warszawy. Produkowano w nich samochody ciężarowe SPa 2TC Polonia (rys. 2), częściowo z polskich części [4].

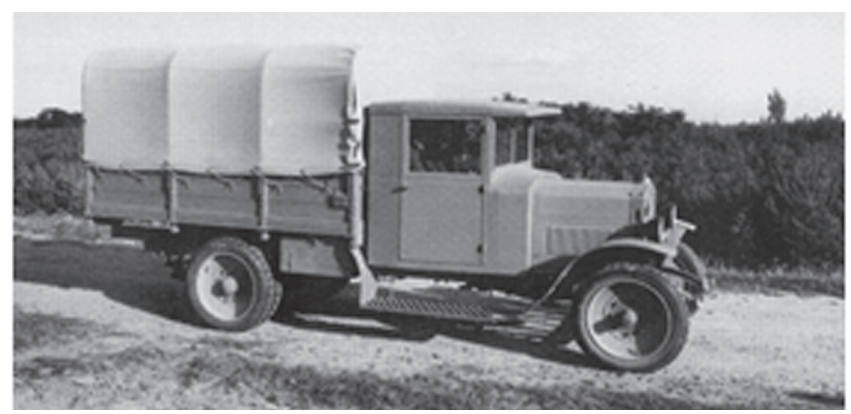

Rys. 2. Samochód ciężarowy Ursus SPa 25C Polonia [6]

Fig. 2. Truck Ursus SPa 25C Polonia [6]

W 1927 r. powstałą w Warszawie fabryka As, produkująca podwozia samochodów osobowych przeznaczonych na taksówki, a rok później fabryka Stetysz, produkująca samochody z podwoziem własnej produkcji i silnikiem amerykańskim. Samochody te, początkowo budowano w Paryżu, a w 1928 r. przeniesiono produkcję do Polski, gdzie w porozumieniu z Tow. Przem. Met. K. Rudzki i Ska, zapoczątkowano montaż z części importowanych i rozpoczęto przygotowania do wytwarzania wszystkich elementów na miejscu [4].

Nadwozia samochodowe wytwarzano w kilku większych firmach, głównie w Lublinie, Poznaniu, Szydłowcu i Białymstoku, a także w szeregu drobnych wytwórni, zlokalizowanych przeważnie w Warszawie [3].

Akcesoriów samochodowych, tj. liczników, reflektorów, wycieraczek itp., a także przyrządów zapłonowych, świec, czy gaźników, w Polsce nie wytwarzano i sprowadzano je z zagranicy $[3,4]$

Mimo niewielkiej produkcji krajowej liczba aut w dwudziestoleciu międzywojennym ciągle rosła. Do 1.VII 1924 r. (pierwsza statystyka Min. Rob. Pub.) w Polsce było zarejestrowanych 8481 samochodów (1 samochód przypadał na 3168 mieszkańców), a w 1928 r. 30000 samochodów (1 samochód na 1174 mieszkańców) [4].

Liczba pojazdów ciągle rosła (rys. 3), jednak w porównaniu z innymi państwami (rys. 4) samochodów w Polsce było niewiele [8].

Lata kryzysu gospodarczego spowodowały spadek liczby aut i dopiero w 1937 r. osiągnięto poziom z końca lat dwudziestych [9].

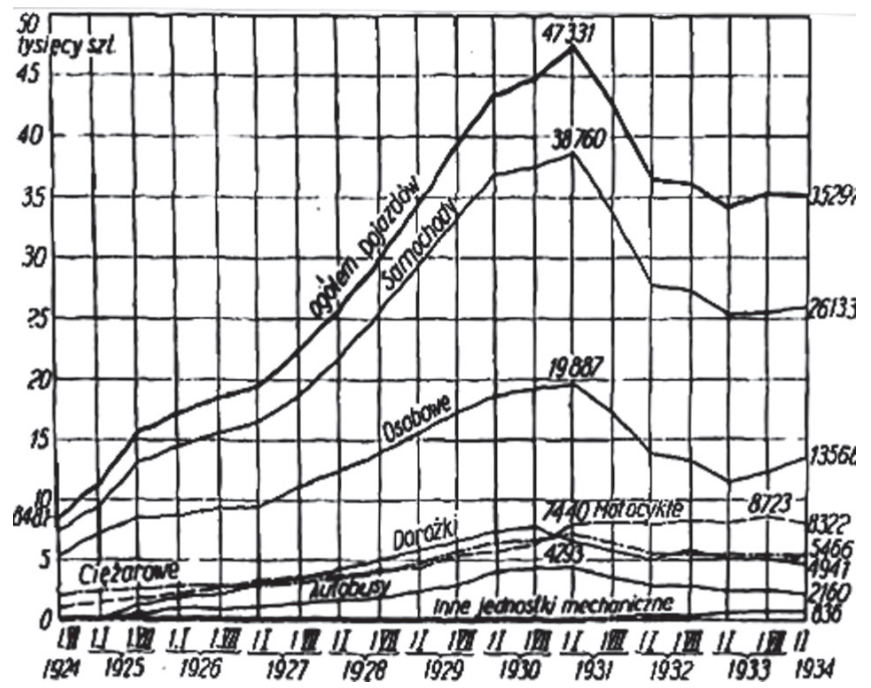

Rys. 3. Liczba pojazdów mechanicznych w Polsce w latach 19241933 [8]

Fig. 3. The quantity of motor vehicles in Poland in the years 19241933 [8]

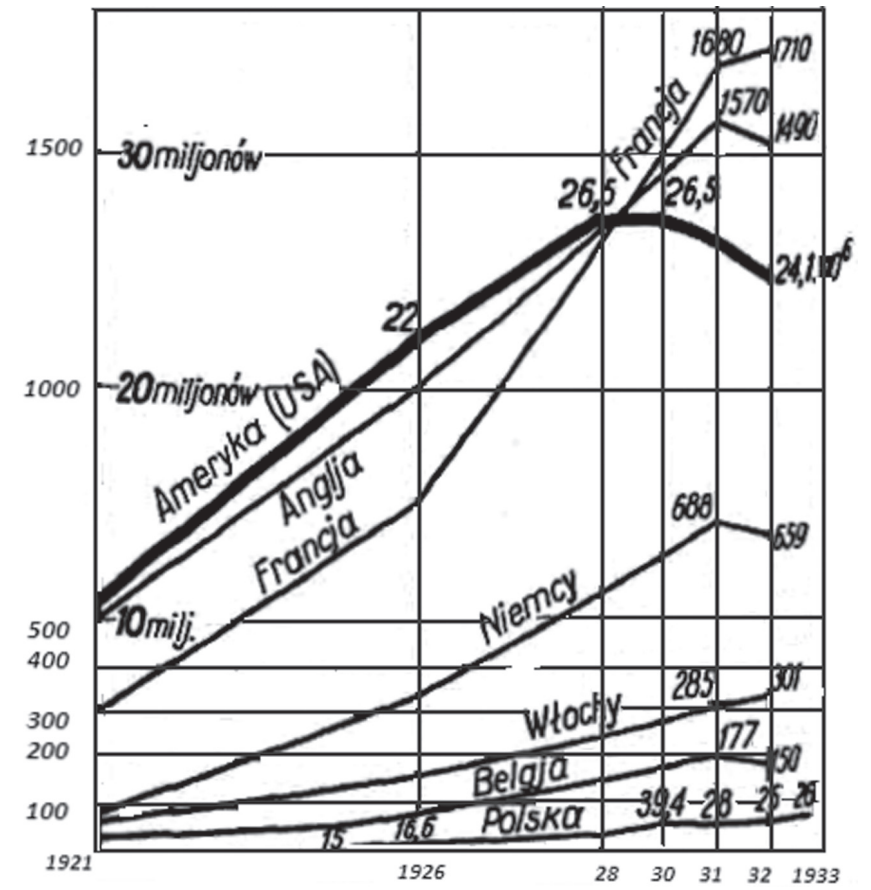

Rys. 4. Liczba samochodów w różnych państwach w latach 1921-1933 [8]

Fig. 4. The guantity of cars in different countries between 1921-1933 [8]

\section{Spawanie w naprawach części samochodowych}

Spawanie w początkowym okresie ograniczało się do robót naprawczych. Stosowano albo lutowanie zużytych elementów, albo spawanie gazowe.

Typowe naprawy w przemyśle motoryzacyjnym obejmowały regenerację bloków silnika, gniazd zaworów, głowic

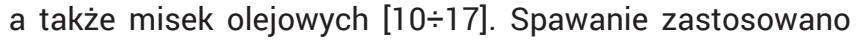
również do napraw skrzyni biegów czy korony koła zamachowego $[18,19]$.

Bloki silników, które były wykonane z żeliwa, spawano metodą gazową , stosując jako materiał dodatkowy pałeczki żeliwne. Bloki przed spawaniem nagrzewano w ognisku z węgla drzewnego. Przy naprawie czterocylindrowego bloku silnika, w którym została wyrwana ścianka, tworząc otwór o wymiarach $250 \times 200$ mm, a także wokół otworu występowały pęknięcia, zastosowano łatę żeliwną o krzywiźnie takiej samej jak krzywizna ścianki. Krawędzi łączonych nie ukosowano, zostawiono tylko odstęp o odpowiedniej szerokości między krawędzią blachy i otworu. W pierwszym etapie spajano pęknięcia, przy czym spoiny układano w kierunku otworu, następnie wstawiono łatę i ją przyspawano. Wewnętrzną powierzchnię cylindra w miejscu naprawionym nadlano do odpowiedniej grubości, a następnie blok wytoczono. Spawanie wraz z przygotowaniem bloku trwało 9 godzin, zużyto $5 \mathrm{~kg}$ karbidu, 1,5 $\mathrm{m}^{3}$ tlenu, 2,5 kg pałeczek żeliwnych oraz 0,25 kg topnika [11].

Naprawa bloku (rys. 5) o grubości ścianki 5 mm, w którym wystąpiły pęknięcia na płaszczu wodnym o całkowitej długości $500 \mathrm{~mm}$ trwała 4 godziny i obejmowała zukosowanie materiału w miejscu wystąpienia pęknięć, nagrzanie bloku i spawanie płomieniem acetylenowo - tlenowym. Do naprawy zużyto $2 \mathrm{~kg}$ karbidu, 0,5 $\mathrm{m}^{3}$ tlenu, 0,25 kg pałeczek żeliwnych [10]. Inną technologię zastosowano przy naprawie 6 cylindrowego bloku silnika (rys. 5), w którym na płaszczu wodnym wystąpiły 2 pęknięcia o długości $500 \mathrm{~mm}$ wzdłuż całego bloku. Ponieważ ścianka między pęknięciami była zdeformowana, wyłamano ją, następnie wyprostowano, zukosowano brzegi na V, wpasowano w ściankę cylindra i spojono [12]. 


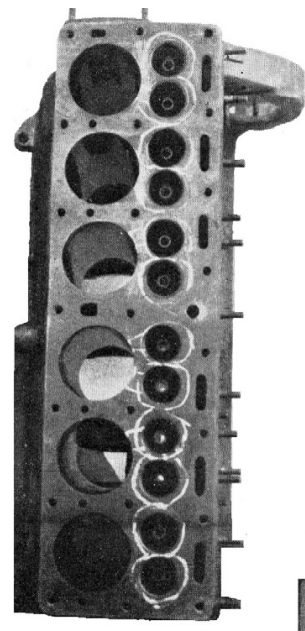

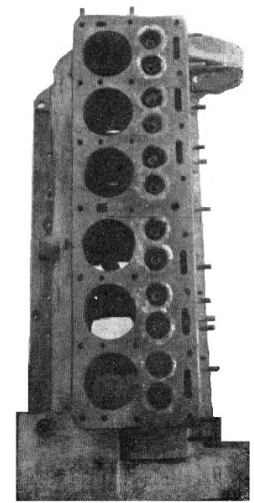

Rys. 5. Blok silnika z zaznaczonymi miejscami zużycia [12]

Fig. 5. The engine block with marked locations of consumption [12]

Wybite gniazda zaworów (rys. 6) napawano po kolei idąc od jednego końca bloku do drugiego. Ponieważ w naprawianym bloku w pięciu miejscach występowały pęknięcia, więc po ich zukosowaniu spawano je w trakcie naprawy gniazd. Spawanie wraz z pracami przygotowawczymi zajęło 2 pracownikom 7 godzin [12].
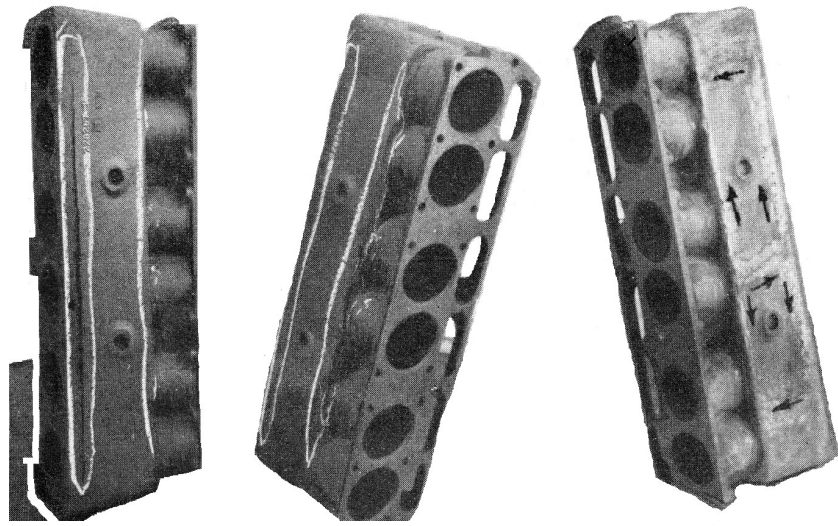

Rys. 6. Blok silnika z zaznaczonymi pęknięciami ścianki i kierunkiem spawania [3]

Fig. 6. The engine block with marked wall cracks and welding Direktion [12]

Przy naprawie głowicy silnika Diesla, której powierzchnia była miejscowo zniszczona na głębokość $4 \mathrm{~mm}$ w wyniku działania korozji, a także występowały pęknięcia w gnieździe zaworu, usunięto palnikiem warstwę materiału na głębokość $8 \mathrm{~mm}$. Na tak oczyszczone podłoże nałożono palnikiem acetylenowo-tlenowym warstwę o odpowiedniej grubości, zapewniającej możliwość dalszej obróbki skrawaniem, jednocześnie spawając pęknięcia. Głowica przed naprawą została nagrzana w ognisku z węgla drzewnego, czas przygotowania do spawania wyniósł 3 godziny, a naprawy 5 godzin. Zużyto $4 \mathrm{~m}^{3}$ tlenu, $16 \mathrm{~kg}$ karbidu, $5 \mathrm{~kg}$ pałeczek żeliwnych, $400 \mathrm{~g}$ topnika oraz $50 \mathrm{~kg}$ węgla drzewnego [15].

Niekiedy przy naprawie głowic, oprócz podgrzania wstępnego stosowano również podgrzewanie w trakcie spawania. Przerywano wówczas proces i umieszczano ponownie głowicę w ognisku. Po naprawie blok obsypywano gorącym popiołem i wolno studzono [1].

Uszkodzenie skrzyni biegów, polegające na urwaniu się łożyska obejmującego wał główny, usunięto również metodą spawania acetylenowo-tlenowego (rys. 7). Krawędzie ukosowano na $\mathrm{V}$, następnie umocowano urwany element przez prowizoryczne dokręcenie płyty do jednej ze ścianek skrzyni, w płycie osadzono wał o odpowiedniej średnicy, na który nasadzono urwaną część. Po spawaniu płytę i wał zdemontowano [18].
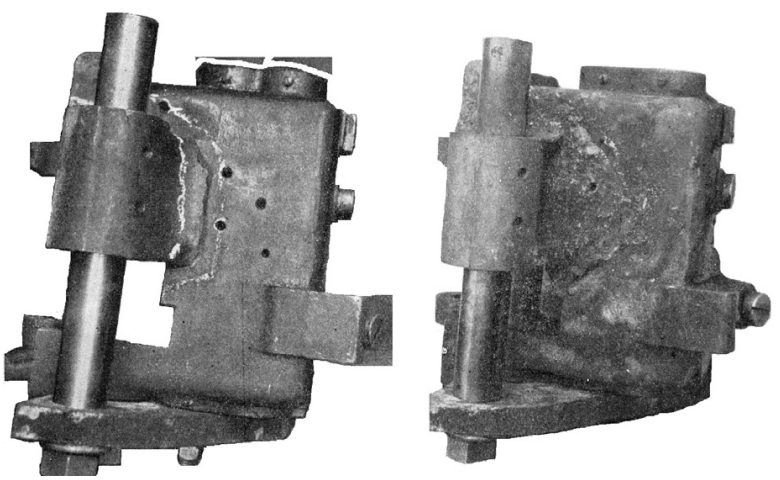

Rys. 7. Skrzynia biegów przed i po naprawie [18] Fig. 7. Transmission before and after rep air [18]

W przypadku elementów wykonanych z aluminium lub jego stopów w naprawach stosowano lutowanie lub spawanie acetylenowo - tlenowe.

Elementy lutowane nagrzewano do temp. min. $250{ }^{\circ} \mathrm{C}$, gdyż nagrzanie do niższych temperatur było niewystarczające, nawet dla bardzo prostych elementów. W przypadku części pracujących na rozciąganie jako lutowia zalecano stosować stopy Al zawierające $7-10 \% \mathrm{Cu}$, duraluminium oraz, dla grubych elementów, stopy Al zawierające $7 \% \mathrm{Cu}$ i $5 \%$ Si. Dla części pracujących na ścieranie zalecano stopy Al zawierające $10 \%$ Cu oraz duraluminium, a dla części narażonych na uderzenia - czyste aluminium [20].

W przypadku spawania przestrzegano ogólnych zasad spawania gazowego aluminium i jego stopów.

W samochodach elementami o znacznych rozmiarach wykonanymi z aluminium były miski olejowe. Miska, w której podczas jazdy kamień wybił otwór o wymiarach 80x80 mm, a także spowodował pęknięcia ścian (rys. 8a) była naprawiona metodą acetylenowo - tlenową. Przed spawaniem brzegi pęknięć zukosowano, a w wybity otwór dopasowano łatę z blachy aluminiowej o grubości równej grubości ścianki miski. Pod miejsca, w których miały być ułożone spoiny podłożono blachę stalową i unieruchomiono ją podpórką (rys. 9). Zastosowanie podkładki było konieczne, gdyż grubość spawanych ścian była znaczna, więc dla uzyskania pełnego przetopu spawacz był zmuszony tworzyć duże i głębokie jeziorko ciekłego metalu. Brak podkładki mógłby powodować powstawanie sopli, a nawet dziur w elemencie spawanym. Miskę przed spawaniem podgrzano w ognisku, do spawania stosowano pałeczki aluminiowe, a kierunek układania spoin przedstawiono na rysunku 8b [16].
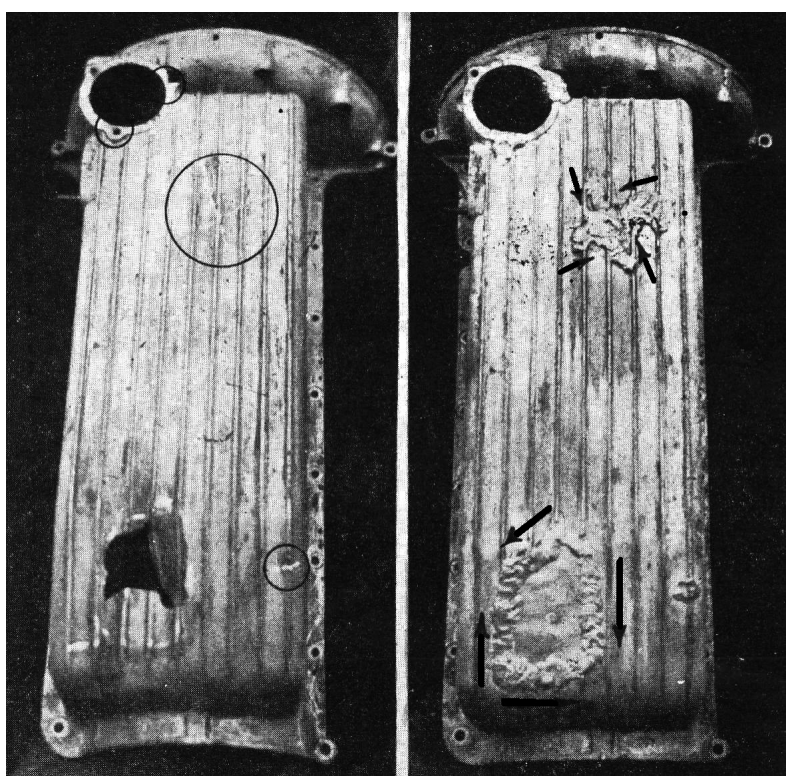

Rys. 8. Miska olejowa przed (a) i po (b) naprawie [16]

Fig. 8. The sump before (a) and after (b) servicing [16] 


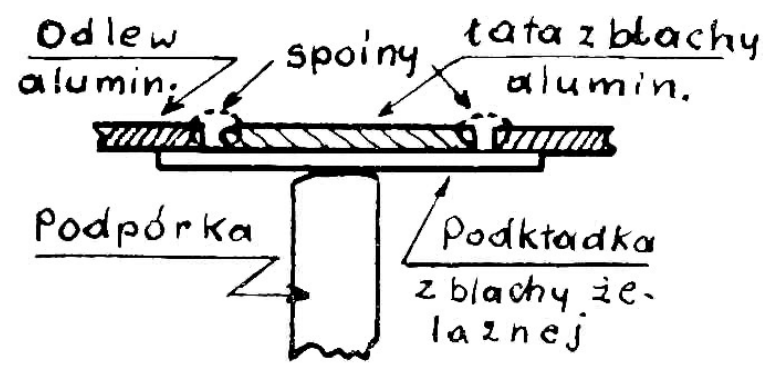

Rys. 9. Sposób przygotowania do spawania miski olejowej [16] Fig. 9. Method for welding the sump [16]

Podobną technologię zastosowano do naprawy miski olejowej 8 cylindrowego silnika samochodu Cadillac. W tym przypadku urwany korbowód spowodował powstanie wyrwy w jednym boku o wymiarach $600 \times 250 \mathrm{~mm}$ i a w drugim wybił otwór wielkości $300 \times 250 \mathrm{~mm}$ (rys. 10). Po dopasowaniu tat i ustawieniu ich na podkładkach układano spoiny od wnętrza w kierunku krawędzi, podgrzewając drugim palnikiem obszar położony naprzeciw miejsca rozpoczęcia spawania. Po spawaniu element był miejscowo nagrzewany, by umożliwić równomierny skurcz ścianek [17].

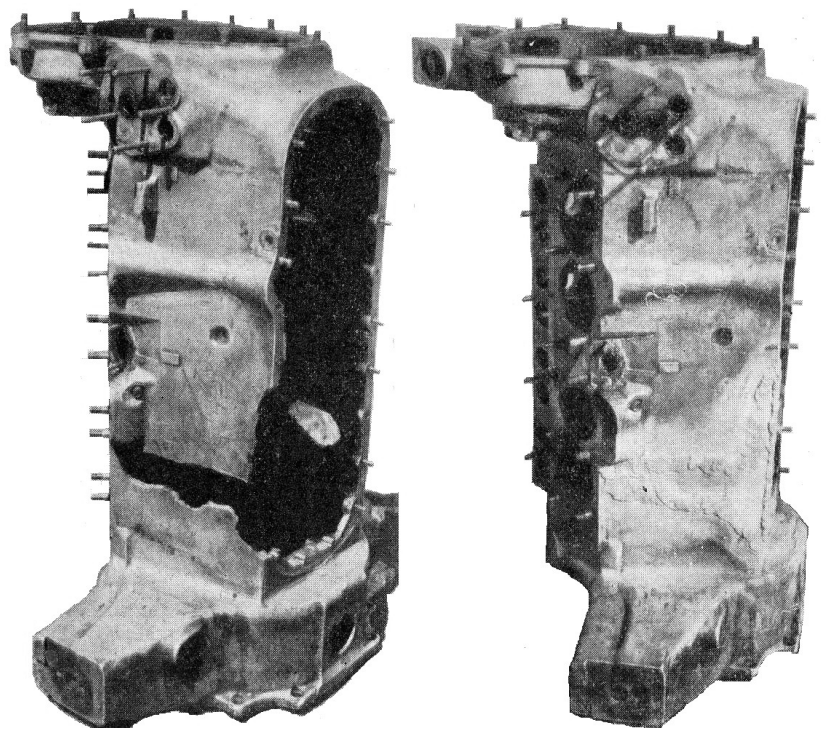

Rys. 10. Miska olejowa samochodu Cadillac przed i po naprawie [17] Fig. 10. Sump before and after rep air [17]

\section{Podsumowanie}

Naprawa ważnych i kosztownych części samochodowych za pomocą spawania lub lutospawania pozwalała wielokrotnie wydłużyć ich żywotność i umożliwiała dalszą eksploatację pojazdów.

\section{Literatura}

[1] Wojciechowski F.: 0 samochodach. Przegląd Techniczny 1897, nr 13, s. 213-216.

[2] M.: Parowozy z motorami. Przegląd Techniczny 1896, nr 6, s. 167168.

[3] Taylor K.: Zapoczątkowanie przemysłu samochodowego w Polsce. Wyd. Przemysł i Handel. Warszawa 1928, s. 170-172.

[4] Taylor K.: Przemysł samochodowy w Polsce i widoki jego rozwoju. Przegląd Techniczny 1924, nr 4, s. 96-100.

[5] Polska motoryzacja w okresie międzywojennym - historia CWS i pierwszy polski samochód. Autokult.pl/2010/12/26/polska-motoryzacja-w-okresie-miedzywojennym

[6] http://www.weu 1918-1939/tabory/ciezarowki/ursus_a html

[7] Prace placówek wytwórczych. Pierwszy samochód polski budowy Cent. Warszt. Samochod. M.S.Wojsk. Przegląd Techniczny 1925, nr 34, s. 33.

[8] Modzelewski W.: Stan obecny, potrzeby i możliwości rozwojowe motoryzacji w Polsce. Przegląd Techniczny 1934, nr 14, s. 486-490.

[9] Kręglewski A.: Zagadnienia sprzętu motoryzacji. Życie Techniczne $1937, \mathrm{nr}$ 9, s. 287-291.

[10] Naprawa bloku samochodowego. Spawanie i Cięcie Metali 1937, nr 6, s. 122.
[11] Naprawa 4-cylindrowego bloku do silnika samochodowego. Spawanie i Cięcie Metali 1937, nr 10, s. 209.

[12] Naprawy silników samochodowych. Spawanie i Cięcie Metali 1937, nr 4, s. 80.

[13] Sznerr A.: Nasze spawalnictwo w naprawach. Spawanie i Cięcie Metali 1934, nr 11, s. 198-203.

[14] Ciekawe naprawy wykonane w warsztatach sp. Akc. Perun Spawanie i Cięcie Metali 1934, nr 9, s. 164-166.

[15] Naprawa głowicy. Spawanie i Cięcie Metali 1937, nr 6, s. 122.

[16] Naprawa aluminiowego karteru samochodowego. Spawanie i Cięcie Metali 1937, nr 1, s. 228

[17] Naprawa aluminiowego karteru 8 cylindrowego silnika samochodowego. Spawanie i Cięcie Metali 1937, nr 9, s. 192.

[18] Naprawa samochodowej skrzyni biegów. Spawanie i Cięcie Metali 1937, nr 9, s. 191

[19] Naprawa korby koła rozpędowego samochodu. Spawanie i Cięcie Metali 1937, nr 7, s. 149.

[20] W.t.: Samorodne spawanie części samochodowych ze stopów glinowych. Przegląd Techniczny 1927, nr 48, s. 1018. 